\title{
REPRODUCTION AND DEVELOPMENT OF DROMICIOPS GLIROIDES (MARSUPIALIA: MICROBIOTHERIIDAE) IN TEMPERATE RAINFORESTS OF SOUTHERN CHILE
}

\author{
REPRODUCCION Y DESARROLLO DE DROMICIOPS GLIROIDES \\ (MARSUPIALIA: MICROBIOTHERIIDAE) EN EL BOSQUE TEMPLADO \\ HUMEDO DEL SUR DE CHILE
}

\author{
Andrés Muñoz-Pedreros ${ }^{1}$, Brian K. Lang ${ }^{2}$, Marta Bretos ${ }^{3}$ \& Peter L. Meserve ${ }^{4}$ \\ ${ }^{1}$ Escuela de Ciencias Ambientales, Universidad Católica de Temuco, Chile. Casilla 15-D, Temuco, Chile. \\ Email:amunoz@uct.cl. \\ ${ }^{2}$ New Mexico Department of Game and Fish, Santa Fe, New México, USA. \\ ${ }^{3}$ Departamento de Ciencias Básicas, Facultad de Medicina, Universidad de la Frontera, Chile. \\ ${ }^{4}$ Department of Biological Sciences, Northern Illinois University, DeKalb, Illinois, USA.
}

\begin{abstract}
The reproductive biology of Dromiciops gliroides is described from five females collected during spring (October, December 1984) in southern continental Chile. Developmental morphology of intra-uterine embryos (October litters) was examined by microscopic analysis and compared with morphological attributes of 8 pouched young (December litters). Intra-uterine embryos demonstrate ontogenetic features characteristic of altricial neonates, which migrate from the urogenital opening to the marsupium in order to complete the later stages of development. D. gliroides apparently is a monoestrus, seasonal breeder producing one litter per year. Maximum recorded litter size is four, with birth occurring in early spring (October). The life cycle of $D$. gliroides is subdivided into seven distinct periods: pair formation, intra-uterine development, parturition, intra-marsupium development, nocturnal family excursions, and juvenile independence. Phylogenetic relationships of $D$. gliroides to Neotropical and Autralian marsupials are considered by comparing aspects of reproductive biology and early life history characteristics.
\end{abstract}

KEYwORDs: Dromiciops gliroides; embryogenesis, reproductive biology.

\section{RESUMEN}

Se describen antecedentes de la biología reproductiva de Dromiciops gliroides provenientes del análisis de cinco hembras colectadas durante la primavera (octubre - diciembre) de 1984 en el sur de Chile. Se examinó el desarrollo morfológico de embriones intrauterinos con análisis microscópico y comparándolos con los atributos morfológicos de ocho juveniles en el marsupio (camadas de diciembre). Los embriones intrauterinos mostraron características embrionarias típicas de neonatos altriciales, quienes migran desde la apertura urogenital hasta el marsupio para completar los últimos estados del desarrollo. $D$. gliroides es, aparentemente, una especie monoéstrica, estacional, produciendo una camada por año. Se ha registrado un máximo de cuatro crías, con nacimientos que ocurren en la primavera temprana (octubre). El ciclo de vida de $D$. gliroides se divide en seis distintos períodos: (a) formación de pareja, (b) desarrollo intrauterino, (c) parición, (d) desarrollo intramarsupial, (e) excursiones familiares nocturnas, y (f) independencia juvenil. Las relaciones filogenéticas de $D$. gliroides con marsupiales del neotrópico y Australia son consideradas comparando aspectos de su biología reproductiva y características de su historia de vida temprana.

Palabras ClaVes: Dromiciops gliroides; embriogénesis, biología reproductiva. 


\section{INTRODUCTION}

The microbiotheriid, Dromiciops gliroides (F. Philippi, 1893), is one of four marsupial species known to occur in Chile. Monotypical and commonly called monito del monte, Dromiciops is endemic to the broad-leaved, temperate rainforests of southern Chile from Curicó $\left(35^{\circ} 30^{\prime} \mathrm{S}\right)$; south to the Isla Grande de Chiloé $\left(42^{\circ} \mathrm{S}\right)$ and adjacent parts of Argentina (Muñoz-Pedreros \& Palma 2000).

The phylogeny and classification of Dromiciops have stimulated much debate amongst mammalian taxonomists (Sharman1982, Gallardo \& Patterson 1987, Marshall et al. 1990, Westerman \& Edwards 1991, Hershkovitz 1992, Palma \& Spotorno 1995, Spotorno et al. 1997). General observations of the life history (Mann 1978, Rageot 1978, Jiménez \& Rageot 1979) and studies of microhabitat selection and trophic specialization (e.g., Pearson 1983, Kelt \& Martínez 1989, Patterson et al. 1990, Kelt et al. 1994) of Dromiciops have broadened our understanding of the autoecology of this sole representative of the Microbiotheriidae. Notwithstanding, the reproductive biology of Dromiciops, as initially described by Mann $(1955,1958)$ and subsequently expounded upon by Greer (1965), Jiménez \& Rageot (1979), and Marshall $(1978,1982)$, remains poorly understood and incompletely described.

We report on the reproductive biology of Dromiciops with the objectives of: describing intra-uterine embryonic morphology from microscopic examination; providing qualitative ontogenetic descriptions of pouched young; and defining the life cycle. These data are compared with early life history and reproductive strategies of New World and Australian marsupials in order to expound upon the contested phylogenetic relationships of the monito del monte to New World and Australian marsupials.

\section{MATERIALS AND METHODS}

All specimens used for this study were collected at "La Picada", a forested valley located in the foothills (400-1100 m) of the Andes range at the base of Volcan Osorno (Chile: Provincia de Osorno, Parque Nacional Vicente Pérez Rosales; $41^{\circ} 02^{\prime} \mathrm{S}, 72^{\circ} 30^{\prime} \mathrm{W}$; $84 \mathrm{~km}$ ESE Osorno). In October and December 1984, 100 museum special snap traps were placed ca. $10 \mathrm{~m}$ apart at elevations of $550 \mathrm{~m}$ and $675 \mathrm{~m}$ for the collection of voucher specimens to complement longoing live-trap studies (Meserve et al. 1992). Traps were baited with a mixture of rolled oats, peanut butter, and canned fish. The lower trap line traversed areas of disturbed, secondary growth forested tracts, while the higher trap line was placed in stands of dense, primary growth rainforest. Habitat physiognomic characteristics were noted at capture sites. All Dromiciops secured in traps were preserved in $10 \%$ formalin. Reproductive tracts were dissected and fixed in 5\% Bouin's solution to prevent desiccation and shrinkage of intra-uterine embryos. Standard morphometric data was recorded for pouched young, and adult individuals. Morphological characteristics of embryos were examined with a stereomicroscope (25X), compared with physical characteristics of pouched young and gross histological analysis of intra-uterine embryos embedded in parafin, sectioned with a microtome (7 microns), and stained with hematoxilin and eosin for subsequent microscopic analysis. Standardized stages for human embryos obtained through the study of the Carnegie Collection (O'Rahilly \& Müller 1987) were used to determine the developmental stage of analyzed embryos. This staging system, based on the degree of development of external and internal morphologic features, has already been employed to examine young marsupials (Nelson 1992).

\section{RESULTS}

The vegetation of the study area corresponds to the "coigüe-ulmo" association (sensu Veblen et al. 1983) of the deciduous Nothofagus and mixed Nothofagus Southern Chilean vegetation sphere (Schmaltz 1991). All Dromiciops' capture sites were located in secondary growth rainforest composed of sparse overstory dominants (Nothofagus dombeyi, Caldcluvia panniculata, Embothrium coccineum; DBH 3.0-25.0 $\mathrm{cm}$ ) and an open canopy cover ( ${ }^{\mathrm{a}} 30-50 \%$ crown closure). For detailed description of the study area see Meserve et al. 1992, 1999. Five female Dromiciops were collected: three individuals in October which had a highly vascularized, swollen uteri with four intra-uterine embryos per female ( $2 \mathrm{R} \times 2 \mathrm{~L})$; and two females in December with four pouch young each. In this latter case, the hairless young were alive and continued to suckle after the death of the lactating female. 


\section{MARSUPIUM}

The marsupium of Dromiciops opens ventrally with a longitudinal aperture and is lined with a soft layer of underfur. Within a sub-cutaneous layer of mammary tissue, a longitudinal ligament divides the marsupium into symmetrical halves paralleling the long axis of the body; each half possessing a pair of teats positioned towards the posterior portion (i.e., lower inguinal region closest to the basicaudal urogenital opening; sensu Hershkovitz (1992)) of the ovoidshaped marsupium. Although internal and external dimensions of the marsupium are not noticeably different $(\mathrm{n}=5$; internal: $\mathrm{x}($ S.E. $)=28.8$ (2.27) L x 14.8 (0.91) W mm; external: $x$ (S.E.) $=30.2(1.46) \mathrm{L} x$ $25.9(2.38) \mathrm{W} ; \mathrm{x}$ (S.E.) teat length $=5.4(0.28) \mathrm{mm})$, the marsupium stretches to accommodate suckling young.

INTRA-UTERINE EMBRYOS

The intra-uterine embryos were in the organogenesis phase of development (sensu Rose 1989); their morphological characteristics were similar to those of stages 14 to 17 of human embryonic development (O’Rahilly \& Müller 1987).

The embryos were externally curved into a C-shape due to the presence of three main body flexures: the apex, cervical and lumbar curvatures. At trunk level, the prominent hepato-cardiac bulk could be observed. The forelimbs were prominent and notably developed, showing three distinct segments. The distal portion formed a great sized foot plate provided with noticeable digit rays in dense mesenchymatic tissue (stage 17).

Several swellings, called facial processes had emerged. The olfatory pits were broad, deep, and surrounded by naso-medial and naso-lateral processes (stage 17). Over them, a depression corresponding to the lens pit could be observed (stage 14). The stomodeum, or primitive oral cavity, was bordered also by maxillary branches of the mandibular arch and by the mandibular processes which were fused in the midline. In a lateral view, the two first visceral arches were observed: the mandibular and the hyoid arches; a cervical sinus was not detected (stage 17). Small auricular hillocks were located on the edges of the hyomandibular cleft (stage 15).

The histological analysis of the embryos revealed little differentiation of the optic region. However, the optic part of the retina (retinal disc), the future pigmented external layer of the retina, and the optic stalk could be distinguished. Retinal disc was invaginating, forming the optic cup. The lens placode, that corresponds to a thickening of the superficial ectoderm immediately overlying the optic cup, had begun to invaginate and deepen into the optic cup (stage 14). The placodic otocyst was elongated dorso-ventrally, constituting the developing inner ear. The vestibular portion showed primary outline, while the cochlear region was only represented by a short diverticulum of the ventral otocystic pole. The endolymphatic appendage was long (stage 15).

Cranial and spinal ganglia were present. The dermomyotome had differentiated in the somites, and separated from the sclerotome.

\section{INTRA-MARSUPIUM YOUNG}

Crown-rump lengths of pouched young with lesser development (December, 14) ranged from 16 to 18 $\mathrm{mm}$, while tail length was $7 \mathrm{~mm}$. Their body was straight at the cervical region, but a wide lumbosacral flexure was still apparent. The body proportions were very different from those of adult animals. The head and the cervical zone length was about one half of the total corporal length, while the trunk occupied the other half. The neck was remarkably bulky. The eyes were closed by the eyelid fusion. The skin surface was naked, wrinkled, and many hair follicles could be observed on the lateral portions of the upper lip and nose. Limbs showed a stout proximal segment, and the fingers of forelimb toes held claws.

The other pouched young (December, 12) showed a more advanced morphological differentiation and corporal growth. Crown-rump lengths measured 22-23 mm, and a tail length of 12-14 mm. At this stage the trunk had lengthened at a greater rate, so that the head and neck have reduced their proportion to only $35 \%$ of the body length. Development of the cephalic region was most distinct near the rostrum where it showed the formation of distinct facial characters: a defined snout, upper lip vibrissae, eyebrows and eyelashes. The eyelids were separated and were slightly open. The pinna of the outer ear was wellpronounced as a result of separation from the cephalic skin. The corporal integument appeared "thicker" and wrinkled, and slight body hair was perceptible. All appendages had grown in length, specially hind limbs. In both litters, forelimb development was more advanced. 


\section{DISCUSSION}

Assuming that sexual maturity occurs in the second year of life (Mann 1958), a life cycle for Dromiciops (Fig. 1) can be proposed from published life history observations and data presented herein (Table I). We divide the life cycle of Dromiciops into seven distinct stages:

I. Pair formation and mating: In late winter to early spring (August-September), mate selection probably occurs through behavioral venues which facilitate sexual encounters between males and females (Papini 1986).

II. Intra-uterine development: Upon conception and blastocyst implantation, a choriovitelline placenta should be formed to nourish intra-uterine embryos. Marsupium development is marked by teat enlargement and formation of lactating tissue. The exact length of intra-uterine development remains unclear, but this period might last for 3-4 weeks until the end of October. Female Dromiciops construct a spherical nest of leaves, mosses, and twigs located 1-2 m above ground within the branches of dense vegetation (Mann 1958; Jiménez \& Rageot 1979).

III. Parturition: At La Picada birth might occur in early November, and neonates have to migrate from the vagina to the marsupium.

IV. Intra-marsupium development: Pouched young seem to remain within the marsupium, firmly affixed to teats, for about two months (November-December).

V. Extra-marsupium development: Increased motor capacities allow pouched young to abandon the marsupium for short exploratory excursions. This exploratory period (late December-January) is marked by excursions, which increase both in frequency and duration as young acquire autonomy. Juvenile Dromiciops continue to suckle during this period and thus occupy the nest as a center for home-range activities.

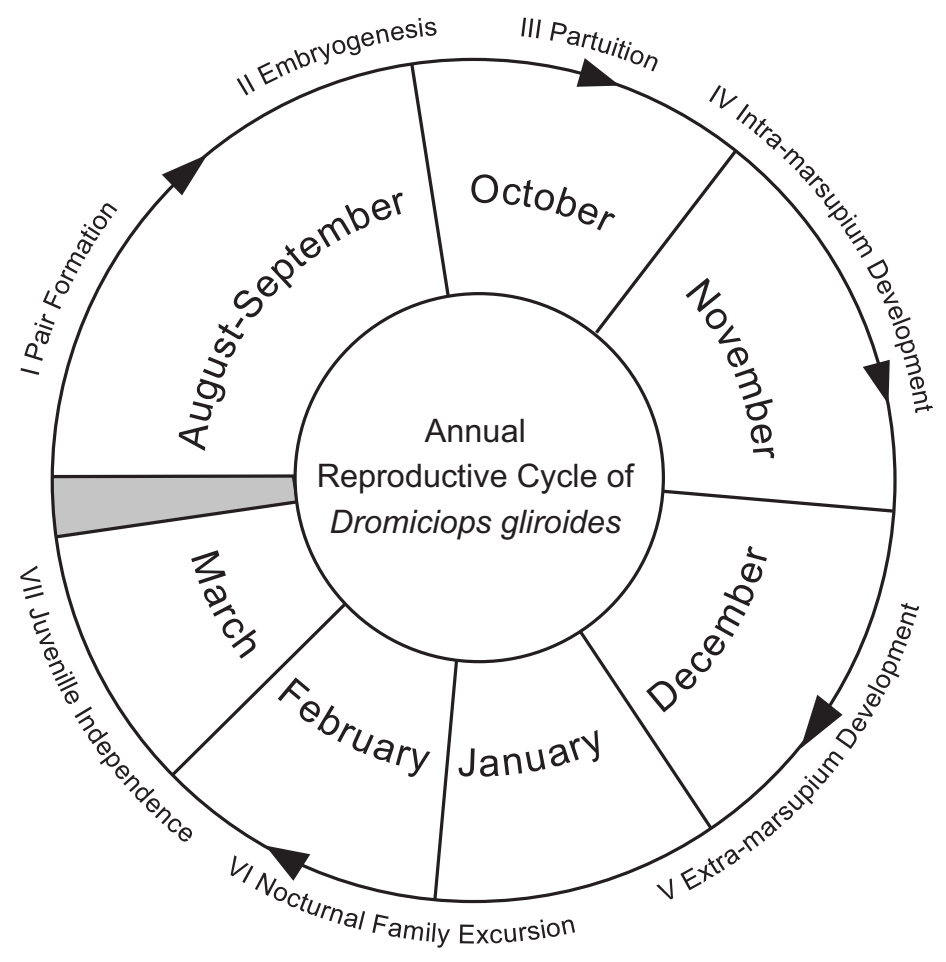

FiguRE 1. Seven stages of the annual life cycle of Dromiciops gliroides Thomas, in southern temperate rainforest of southern Chile.

Figura 1. Siete etapas del ciclo de vida anual de Dromiciops gliroides Thomas, en la selva templada lluviosa del sur de Chile. 
Reproduction of Dromiciops gliroides: MuÑoz-Pedreros, A. ET AL.

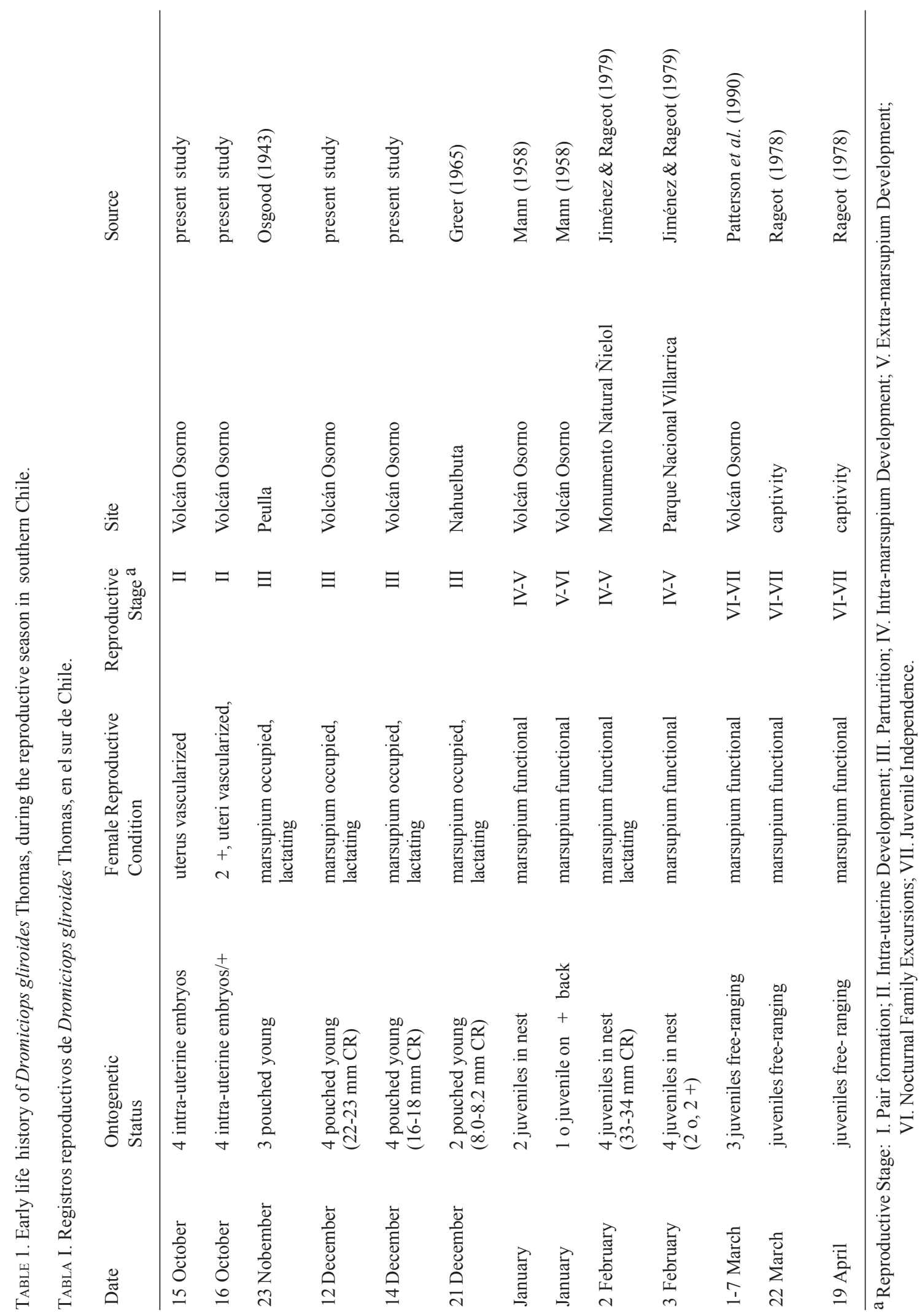


VI. Nocturnal family excursions: Eventually the maturing juveniles accompany the female during nightly forays by clinging to her back (Mann 1978), as in Didelphis (Hunsaker 1977). Although these gregarious nocturnal ventures continue through February, juveniles frequently abandon the mother's carriage for solo foraging and exploratory excursions while remaining in close proximity to each other.

VII. Juvenile independence: By the end of March, juvenile Dromiciops are autonomously free-ranging even though the female's marsupium is still well-developed with functional teats (Lang, pers. observ.); suggesting that juveniles are not totally weaned until cessation of the reproductive season in April.

Intra-uterine embryonic growth rates have been used to clarify underlying dichotomous patterns of marsupial-eutherian reproduction (Tyndale-Biscoe 1973,1974,1979, Mcnab 1980, Lee \& Cockburn 1985, Rose 1989). Calculation of embryonic growth rates for eutherian mammals has typically followed Hugget \& Widdas (1951). Rose (1989) provided embryonic growth rates for 13 species of marsupials. Quantification of mammalian embryonic organogenesis requires accurate measurements of neonatal birth weights within the first 24 hours after birth (Frazer \& Huggett 1974), lengh of gestation period (Rose 1989), and latency to primitive streak formation (Selwood 1980). Such data are typically derived from captive-reared individuals, and remain unknown for Dromiciops. Nonetheless, the life cycle defined herein does provide insight into the early life history of the monito del monte.

Reproductive stages II-III are partly documented by this study. The period corresponding to stages IVVII is corroborated by life history observations compiled from published sources and data reported from concurrent field studies (Meserve et al. 1988, 1992; Patterson et al. 1989, 1990, Kelt et al. 1994). At the foot of Volcán Osorno in January, Mann (1958) captured a live female monito del monte in close proximity to a nest containing two juveniles, which correspond to Stage V (Extra-marsupium Development). During intensive trapping efforts at La Picada (late February through mid-March; Patterson et al. 1990), multiple snap-trap captures of juvenile and adult Dromiciops were observed on numerous occasions within a $5 \mathrm{~m}$ radius and on the same trap night (Lang \& Meserve pers. observ.). This suggests that juvenile Dromiciops explore the general nest area in family groups with the adult female remaining in close proximity to her young (Stage VI: Nocturnal Family Excursions). While juveniles may forage during these explorations, the proximity to their presumed parents suggests that they are not completely weaned from the mother. Although cessation of the reproductive period is not well documented, perhaps in part due to Dromiciops bias against live-traps (Patterson et al. 1989), it appears that the marsupium is unoccupied by May (Meserve pers. observ.). Duration of dependence in juvenile Dromiciops, as much in the marsupium as in the nest, lasts approximately four months (November-February), and is considerably longer than the documented period for other insectivorous-omnivorous New World marsupials (ca. 56-100 days, Harder 1992). In general, small insectivorous-omnivorous marsupials have longer periods of juvenile dependence than similarlysized carnivorous species (Russell 1982, Lee \& Cockburn 1985). Availability of food resources typically plays an important role in the weaning of juvenile marsupials, especially for macropodid species where seasonal production of protein food items is synchronized with juvenile weaning (Lee \& Cockburn 1985).

Although seasonal diet shifts are anticipated, Meserve et al. (1988) reported that the monito del monte is primarily insectivorous, despite a demonstrated tendency towards omnivory in captivity (Kelt \& Martínez 1989). Further research on seasonal dietary variation of Dromiciops would not only help to elucidate seasonal trophic specializations with respect to the reproductive cycle, but would also provide insight into the physiological response(s) of the monito del monte during the winter period of reduced activity.

Ontogeny of intra-uterine Dromiciops described herein correspond to observations of previous research on marsupials. In particular, development of features required for the migration towards the marsupial opening (i.e., well-developed olfactory placode, stomodeum, forelimbs) and prenatal adaptations (i.e., olfaction, dactyl flexion, and limb movement) characteristics of altricial young were noted in stages of advanced ontogeny compared to other embryonic organ and neuro-muscular systems (Ulinski 1971, Barbour 1977, Barnes 1977, Hunsaker 1977, Johnson 1977, Parker 1977, Lee \& Cockburn 1985). Such precocious development of selected embryonic traits plays an important role in neonatal movement from the vagina to the marsupium. This 
migration, implies maturity and functioning of the pyramidal tract, motor cortex, and rhinencephalon, neuromuscular control of the forelimb, and physiological adaptations related to pulmonary and possibly cutaneous gaseous exchange (Tyndale-Biscoe 1973). Prenatal organ systems not vital to the survival of intra-marsupium embryos (i.e., eyes, ears, reproductive tract) were mostly underdeveloped even in pouch young. Development of adult organ systems in fetal Dromiciops seems to proceed at a very rapid rate once neonates achieve teat attachment within the marsupium.

Litter size of Dromiciops is similar to that of some New World didelphid marsupials, such as Chironectes minimus, Didelphis albiventris (3.5 and 4.2 fetuses/litter, respectively; Hunsaker 1977), Caluromys philander (4.1 fetuses/litter; CharlesDominique et al. 1983), and Philander opossum (3.4 fetuses/litter; Eisenberg \& Wilson 1981). The maximum number of Dromiciops pouch young suckling at any one time is four (Patterson \& Rogers 1995). Although Hunsaker (1977) mentions 2-5 pouch Dromiciops, we conclude that litter size of the monito del monte ranges from two to four pouch young based on physical limitations imposed by the marsupium proper and teat formula.

Whereas most New World marsupials are seasonally polyestrus, attempting at least two litters during a given breeding season (Lee \& Cockburn 1985, Harder 1992), Dromiciops seems to be a monoestrus, seasonal breeder producing one litter per year. Climatic constraints may serve as an ultimate factor controlling seasonal reproductive pattern of Dromiciops, as documented for several sigmodontine rodents of temperate rainforests of southern Chile (Meserve et al. 1982, 1988).

Seasonal cessations of activity are reported for Dromiciops by Mann (1978) who termed it as "winter sleep" or torpor. This involves a pronounced decrease in the animal's basal metabolic rate for prolonged periods of time in response to inclement winter weather typical of southern Chilean temperate rainforests (Redford \& Eisenberg 1992). Prior to beggining of torpor, Dromiciops accumulates fat in subcutaneous oily deposits at the base of the tail (Kelt \& Martínez 1989; Patterson \& Rogers 1995). There is some degree of minimal activity during this period, consistent with the fact that intensive live-and snap-trapping efforts throughout the entire Valle de La Picada (1981-85) produced notably fewer
Dromiciops captures in winter (June-September) than in other seasons (spring-fall) (Meserve et al. 1988, 1992; Patterson et al. 1989; Kelt et al. 1994). In fact, only two Dromiciops (23-24 g males) were captured during all winter seasons from 1981-85 (Meserve unpub. data). The exact role of this seasonal torpor and its effects on the reproductive cycle of Dromiciops, in particular, control of estrus, remain obscure and merit further attention. Such seasonal activity patterns may strongly influence the estrus cycle, which most likely starts with ovulation in late winter-early spring (September) once Dromiciops resumes normal activity patterns upon arousal from winter torpor.

Phylogenetic relationships of Dromiciops to New World and Australasian marsupials have been the subject of extensive debate among systematists. The postulate of a closer relationship between Dromiciops and Australasian marsupials has been supported by ankle bone articulation patterns (Szalay 1982), chromosomal studies (Sharman 1982, Alpin \& Archer 1987), sperm morphology (Temple-Smith 1987), and systematic studies (Marshall 1987). An absolute affinity of Dromiciops to either Ameridelphia or Australidelphia marsupials, as proposed by Szalay (1982), has not been considered by others, who argue that autapomorphic cranial, dental, anatomical, and serological characters separate Dromiciops as a highly derived marsupial clade that evolved independently from metatherian stock (Westerman \& Edwards 1991, Hershkovitz 1992). Early life history and reproductive biology of Dromiciops described by this study inconsistently support the affinity of the monito del monte to either Ameridelphia or Australidelphia (Szalay 1982); further studies might support the hypothesis that Dromiciops would be a highly derived marsupial which is the only modern representative of a clade distinct since the upper Cretaceous (Westerman \& Edwards 1991, Hershkovitz 1992).

\section{ACKNOWLEDGMENTS}

We thank Drs. P. Hershkovitz, D. A. Kelt, P. Marquet, E. Palma, and B.D. Patterson for valuable comments on the manuscript. The Corporación Nacional Forestal de Chile granted permission to conduct research studies within the boundaries of Parque Nacional Vicente Pérez Rosales. Northern Illinois University 
provided logistical support for the project. Logistical support for Laboratory work of Muñoz-Pedreros and Bretos was provided by Universidad Católica de Temuco, and Universidad de la Frontera. Funding for field support came from the Northern, Illinois University and from NSF INT-8018631 and NSF INT-8382724.

\section{BIBLIOGRAPHY}

Alpin, K. R. \& M. ARCHER. 1987. Recent advances in marsupial systematics, with a new syncretic classification in Possums and Opossums: Studies in Evolution, Vol. 1, pp. xv-lxxii (M. Archer, ed.) Roy. Zool. Soc. NSW, Sydney.

BARBour, R.A. 1977. Anatomy of marsupials. pp. 137 272. In The Biology of Marsupials. (B. Stonehouse and D. Gilmore, eds.) Macmillan Press, London.

BARnes, R.D. 1977. The special anatomy of Marmosa robinsoni. pp. 387-412. In The Biology of Marsupials. (D. Hunsaker, II, ed.) Academic Press, Inc., New York.

Charles-Dominique, P. 1983. Ecology and social adaptation in didelphid marsupials: comparisons with eutherians of similar ecology. pp. 395-422. In Recent Advances in the Study of Mammalian Behavior. (J.F. Eisenberg and D. G. Kleiman, eds.), Am. Soc. Mamm. Spec. Pub. 7.

EISENBERG, J. F. \& D.E. Wilson. 1981. Relative brain size and demographic strategies in didelphid marsupials. Am. Nat. 118:1-15.

Frazer, J. F. \& A. Huggett St. G. 1974. Species variations in the foetal growth rates of eutherian mammals. J. Zool. 174:481-509.

Gallardo, M.H. \& B.D. Patterson. 1987. An additional 14-chromosome karyotype and sex-chromosome mosaicism in South American marsupials. Fieldiana 39:111-115.

Greer, J.K. 1965. Mammals of Malleco Province, Chile. Pub. Mus., Michigan State University, Biol. Ser. 3: $59-152$.

HARDER, J.D. 1992. Reproductive biology of South American marsupials. pp. 211-228 in Reproductive Biology of South American Vertebrates (W. C. Hamlett, ed.), Springer-Verlag, Inc., New York.

Hershkovitz, P. 1992. Ankle bones: the Chilean opossum Dromiciops gliroides Thomas, and marsupial phylogeny. Bonn. Zool. Beitr. 43:181-213.

Hugget, A. \& W.F. Widdas St. G. 1951. The relationships between mammalian foetal weight and conception age. J. Physiol. 114:306-317.

Hunsaker, D. 1977. Ecology of New World marsupials. pp. 95-156. In the Biology of Marsupials, (D. Hunsaker, II, ed.), Academic Press, Inc., New York.

JimÉnez, J. \& R. RAgeot. 1979. Notas sobre la biología del monito del monte (Dromiciops australis, Phillipi 1893). An. Mus. Hist. Nat. 12:83-88.

JOHNSON, J. I. JR. 1977. Central nervous system of marsupials. pp. 159-278. In The Biology of Marsupials, (D. Hunsaker, II, ed.). , Academic Press, Inc., New York.

Kelt, D.A. \& D.R. Martínez. 1989. Notes on distribution and ecology of two marsupials endemic to the valdivian forest of southern South America. J. Mamm. 70:220-224.

Kelt, D.A., P.L. Meserve \& B.K. LANG. 1994: Quantitative habitat associations of small mammals in a temperature rainforest in southern Chile. Empirical patterns and the importance of ecological scale. J. Mamm. 75:890-904.

Kirsch. J. A. W., A.W. Dickerman, O.A. Reig \& M.S. SPRINGER. 1991. DNA hybridization evidence for the Australian affinity of the American marsupial Dromiciops australis. Proc. Nat. Acad. Sci. 88: 10465-10569.

LeE, A.K. \& A. CockBurn. 1985. Evolutionary Ecology of Marsupials. Cambridge Univ. Press, London.

ManN, G. 1955. Monito del monte Dromiciops australis Phillipi. Inv. Zool. Chilenas, 2: 159-166.

Mann, G. 1958. Reproducción de Dromiciops australis (Marsupialia, Didelphidae). Inv. Zool. Chilenas 4: 209-213.

Mann, G. 1978. Los pequeños mamíferos de Chile. Gayana: Zoología 40:1-132.

Marshall, L. G. 1978. Dromiciops australis. Mammalian Species 99:1-5.

Marshall, L. G. 1982. Systematics of the South American marsupial family Microbiotheriidae. Fieldiana: Geol. New Ser. Nº 10:1-95.

Marshall, L. G. 1987. Systematics of Itaboraian (Middle Paleocene) age "opossum-like" marsupials from the limestone quarry at Sao José de Itaborai, Brazil. Pp. 91-160. In Possums and Opossums: Studies in Evolution, Vol. 1 (M. Archer, ed.), Roy. Zool. Soc. NSW, Sydney, Australia.

Marshall, L. G., J.A. Case \& O. Woodburne. 1990. Phylogenetic relationships of the families of marsupials. Pp. 433-505. In Current Mammalogy, H.H. Genoways, ed. Plenum Press, New York.

MCnAB, B. K. 1980. Ecological and behavioral consequences of adaptation to various food resources. Pp. 664-697. In Advances in the Sudy of Mammalian Behavior, J.F. Eisenberg and D.C. Kleinman , eds., Am. Soc. Mamm. Spec., Publ. 7.

Meserve, P.L., R. Murua, N.O. Lopetegui \& J.R. Rau. 1982. Observations on the small mammal fauna of a primary temperate rainforest in southern Chile. J. Mamm. 63: 315-317.

Meserve, P.L., B.K. Lang \& B.D. Patterson. 1988. Trophic relationships of small mammals in a Chilean temperate rainforest. J. Mamm. 63:721-730.

Meserve P.L., B.K. Lang, R. Murua, A. Muñoz-Pedreros \& L.A. GonZÁLEZ. 1992. Characteristics of a terrestrial small assemblage in a temperate rainforest in Chile. Rev. Chilena Historia Natural 64: 157-169. 
Reproduction of Dromiciops gliroides: MuÑoz-PEDRERos, A. ET AL.

Meserve P.L., D.R. Martínez, J. Rau, R. Murua, B. LANG \& A. MuÑoz-Pedreros. 1999. Comparative demography and diversity of small mammals in precordilleran temperate rainforest of southern Chile. J. of Mamm. 80: 880-890.

Muñoz-Pedreros A. \& R.E. Palma. 2000. Marsupiales. In Mamíferos de Chile. Ed. by A. Muñoz-Pedreros \& J. Yáñez (pp: 43-51). CEA Ediciones. 464 pp.

Nelson, J.E. 1992. Developmental staging in a marsupial Dasyurus hallucatus. Anat. Embryol. 185: 335-354.

O’RAHILly R. \& F. MülleR. 1987. Developmental Stages in Human Embryos. Including a Revision of Streeter's "Horizonts" and a Survey of the Carnegie Collection. Carnegie Instn. Wash. Publ. 637, Washington, D.C. 306 pp.

Palma R.E. \& A.E. Spotorno. 1995. El enigma de un fósil viviente: el marsupial chileno Dromiciops. Noticiero de Biología 3(2):21-24.

Papini, M. 1986. Psicología comparada de los marsupiales. Revista Latinoamericana de Psicol. 18:215-246.

PARKER, P. 1977. An ecological comparison of marsupial and placental patterns of reproduction. Pp. 273286. In The Biology of marsupials (B. Stonehouse and D. Gilmore, eds.), Macmillan Press, London.

Patterson, B.D. \& M.A. Rogers. 1995. Family Microbiotheriidae. In Mammals of South América, A.L. Gardner, ed., University of Chicago Press, Chicago (in press).

Patterson, B.D., P.L. Meserve \& B.K. Lang. 1989. Distribution and abundance of small mammals along an elevational transect in temperate rainforests of Chile. J. Mamm. 70:67-78.

Patterson, B.D., P.L. Meserve \& B.K. Lang. 1990. Quantitative habitat associations of small mammals along an elevational transect in temperate Chilean rainforests. J. Mamm. 71:620-633.

PeArson, O.P. 1983. Characteristics of a mammalian fauna from forests in Patagonia, southern Argentina. J. Mamm. 64:476-492.

Rageot, R. 1978. Observaciones sobre el Monito del Monte. Corp. Nac. For. de Chile. Mat. Fot. 17 pp.

RedFord, K.H. \& J.F. Eisenberg. 1992. Mammals of the Neotropics: the Southern Cone - Chile, Argentina, Uruguay, Paraguay. Univ. of Chicago Press, Chicago.

Rose, R.W. 1989. Embryonic growth rates of marsupials with a note on monotremes. J. Zool. 218:11-16.
RusSELL, E.M. 1982. Patterns of parental care and parental investment in marsupials. Biol. Rev., 57:423486.

Schmaltz, J. 1991. Deciduous forests of southern South America. Pp. 557-578. In Ecosystems of the World 7: Temperate Deciduous Forests (E. Röhrig and B. Ulrich, eds.), Elsevier Press, New York.

SELwoOd, L. 1980: A timetable of embryonic development of the dasyurid marsupial Antechinus stuartii (MacLeay). Aust. J. Zool. 28:649-668.

Sharman, G.B. 1982. Karyotypic similarities between Dromiciops australis (Microbiotheriidae, Marsupialia) and some Australian marsupials. Pp. 711-714 in Carnivorous Marsupials, (M. Archer, ed.), Roy. Zool. Soc. NSW, Sydney, Australia.

Spotorno A.E., J.C. Marín, M. Yévenes, L. Walker, R. Fernandez-Donoso, J. Pincheira, S. Berrios \& R.E. Palma, 1997. Chromosome Divergences Among American Marsupials and the Australian Affinities of the American Dromiciops. Journal of Mammalian Evolution 4(4):259-269.

SzaLAY, F.S. 1982. A new appraisal of marsupial phylogeny and classification. Pp 612-640. In Carnivorous Marsupials (M. Archer ed.), Roy. Zool. Soc. NSW, Sydney, Australia.

Temple-Smith, P. 1987. Sperm studies and marsupial phylogeny. Pp. 171-193. In Possums and Opossums: Studies in Evolution, Vol. 1 (M. Archer, ed.), Roy. Zool. Soc. NSW, Sydney, Australia.

Tyndale-Biscoe, C.H. 1973. Life of Marsupials. Edward Arnold, London.

Tyndale-Biscoe, C.H. 1974. Reproduction in marsupials Aust. Mamm, 1:175-180.

Tyndale-Biscoe, C.H. 1979. Ecology of small marsupials. Pp. 343-379 in Ecology of Small Mammals. (D.M. Stoddard, ed.), Chapman \& Hall, London.

ULINSKI, P.S. 1971. External morphology of pouch young opossum brains: a profile of opossum neurogenesis. J. Compar. Neurol. 142:33-58.

Veblen, T.T., F.M. Schlegel \& J.V. Oltremari. 1983: Temperate broad-leaved evergreen forests of South America. Pp. 5-31. In Temperate Broadleaved Evergreen Forests, (J.D. Ovington, ed.), Elsevier Scientific Publications B.V., Amsterdam, Netherlands.

Westerman, M. \& D. Edwards. 1991. The relationship of Dromiciops australis to other marsupials: data from DNA-DNA hybridisation studies. Austr. J. Zool. 39: 123-131.

Fecha de recepción: 12/03/05

Fecha de aceptación: 15/08/05 